馬場茂雄1)、朝原庸光1)、飯田理文1)、富沢宏樹1)、立石満1)、宮崎浩2)

1) 根本特殊化学ライフサイエンス研究所、2) 新潟薬科大学

\title{
VALIDATION STUDIES OF RADIOLUMINOGRAPHY
}

Shigeo BABA1), Nobumitsu ASAHARA1), Satofumi IIDA1), Hiroki TOMISAWA1), Mitsuru TATEISHI1), and Hiroshi MIYAZAK|2)

1) Nemoto Life Science Laboratories, Ohnogoh, Mitsukaido,300-2521.

2) Niigata College of Pharmacy, Kamishinei, Niigata, 950-2076.

[目的] RLG は、本シンポジウムのフォーラム (1992 年) でも取り上げられた優れた 2 次元放射能 検出法である。最近、15 施設が参加したバリデー ション分科会から BAS や IP の性能に関する報告1) が公表されたが、RLGのバリデーションでは何を なすべきか、また RLG は信頼できる方法であるか について結論が得られていない。放射能は Bq 単位 で表示されるべきであるが、測定値の表示にPSL が使用され続けている。演者らは、RLGをバリ デートし、Bq 単位で表示する方法を開発した。 [理論] まず、RLG の検出特性を考える。ある関心 領域 $(\mathrm{ROI})$ に $A \mathrm{~Bq}$ の $\mathrm{RI}$ を含む測定試料を一定時間 IP に露光した後直ちに解析して得られる PSL 值、 PSLOB は式 1 で与えられる。

$$
P S L_{O B}=k_{I P} \cdot f \cdot A+P S L_{B G} \quad \text { 式 } 1
$$

$k_{\mathrm{IP}}$ (感度) は、 $1 \mathrm{~Bq}$ の RI から放射された全放射線 がIP に入射したと仮定したときの PSL 值である。 感度は、IP が放射線のエネルギーを吸収する効率 と、BAS がこの吸収されたエネルギーをPSL とし て読取る効率の積である。 $f$ は検出効率で、幾何学 的効率、測定試料とIP の間に存在する物質による 吸収及び自己吸収 $\left(f_{\mathrm{s} . \mathrm{ab}}\right)$ などによって左右される が、1 枚の IP で測定された一連の試料においては、 これらのうちで変動するのは $f_{s . a b}$ だけである。 $k_{l P} \cdot f$ を精確に求めることは困難であるので、BG 試料を 置いた領域 $\left(R O I_{\mathrm{BG}}\right)$ の PSL 值を $P S L_{B G}$ とし、標準 試料を置いた領域 $\left(R O I_{S T}\right)$ の net PSL 值から $k_{\mid P} \cdot f$ を求め、Aを算出する方法が採られている。式 1 か ら RLG のバリデーションは感度と BG の均一性を 試験し、これらに不均一性が認められた場合にはそ れを補正することに帰することが分かる。個々の
IPやBAS の感度はあまり問題にならないこと、ま た $f_{\mathrm{s} . \mathrm{ab}}$ を補正することによって Bq 表示が可能にな ることを強調しておく。

[実験方法と結果] 感度の不均一性には、IP と BAS が係わっているが、実際には両者が重なった 状態でしか観察されない。両者がどのような割合で 貢献しているかを、147Pm 平面線源2）に照射した IP に見られるPSLOB の分散を解析することにより検 討した。この場合、PSLOB に不均一性が現れる要 因として ${ }^{147 P m}$ 平面線源、IP 及び BAS の 3 つが考 えられる。2 台のBAS、 4 枚のIP を使って得られ た計測結果を分割法により解析することによって、 感度の不均一性の主因は BAS の PSL 読取り効率に あることが実証された。

BAS の感度均一性試験 Fig. $1 \mathrm{~A}$ は、 $147 \mathrm{Pm}$ 平面 線源に10 分間露光した IP について周辺部 $10 \mathrm{~mm}$ を 除き、 684 区画 $(10 \times 10 \mathrm{~mm})$ のPSL の分散を、 BAS A で調べた結果である。RSD は $1.92 \%$ でこの 種の機器としては満足すべき值であるが、BAS B の RSD は $3.64 \%$ であった。次の問題は、この不均 一性を補正する方法を開発することである。演者ら は、 ${ }^{147 P m}$ 平面線源に露光した IP を解析し、ピク セル単位で感度補正して ROIST における感度に PSL 值を基準化 "normalize" する方法を提案する。 この処理によって PSL の分散の RSD は著しく向上 することが分かった (Fig. 1B)。

$P S L_{B G}$ の均一性試験 RLGによる測定は、BGは IP 全面にわたって均一であることを前提にしている が、この前提そのものが根拠薄弱である。PSL $\mathrm{BG}$ を不均一にする要因として感度の他に遮蔽における 不均一と IP の RI 污染が挙げられる。IP の污染を検 
査する方法及び各 $R O I$ の $P S L_{B G}$ を直接測定する方 法として重ね合わせ法を提案する。その骨子は、測 定用 IP または污染検査をするIPにBG 補正用 IP を 重ねて露光し、後者の $P S L_{B G}$ から各 ROI の PSL $L_{B G}$ を直接求めることに加えて、污染情報を得ることに ある。実験結果の一例を Fig. 2 に示した。この図か ら $P S L_{B G}$ は周期的に変化すること及び提案した方 法によって PSL $L_{B G}$ が絶対誤差の平均 5 PSL の精度 で求められることが分かった。

[結論] 1. RLG のバリデーションは、感度と $P S L_{B G}$ の不均一性を試験し、不均一性が認められ た場合にはそれらを補正することである。

2. 感度の不均一性は BAS の PSL 読取り機構にあ ることを実証し、これを補正する方法を提案した。 3. 露光時の遮蔽を強化すると、遮蔽強度むらによ る $P S L_{B G}$ の不均一性が現れる。任意の ROI の $P S L_{B G}$ を精確に求め、IP の污染検査を可能にす る、重ね合わせ法を提案した。精確な $P S L_{B G}$ の測 定によって液シン100 分計測の精度が得られる。 4. $147 \mathrm{Pm}$ 平面線源を用いて WBA 切片各臓器の厚 さを求め2)、 $f_{\text {s.ab }}$ を補正することによりWBA によ る正確な絶対測定ができ、Bq 単位表示が初めて可
能になった。この方法は液シンによる摘出藏器計数 法よりも精度の高(方法である3)。
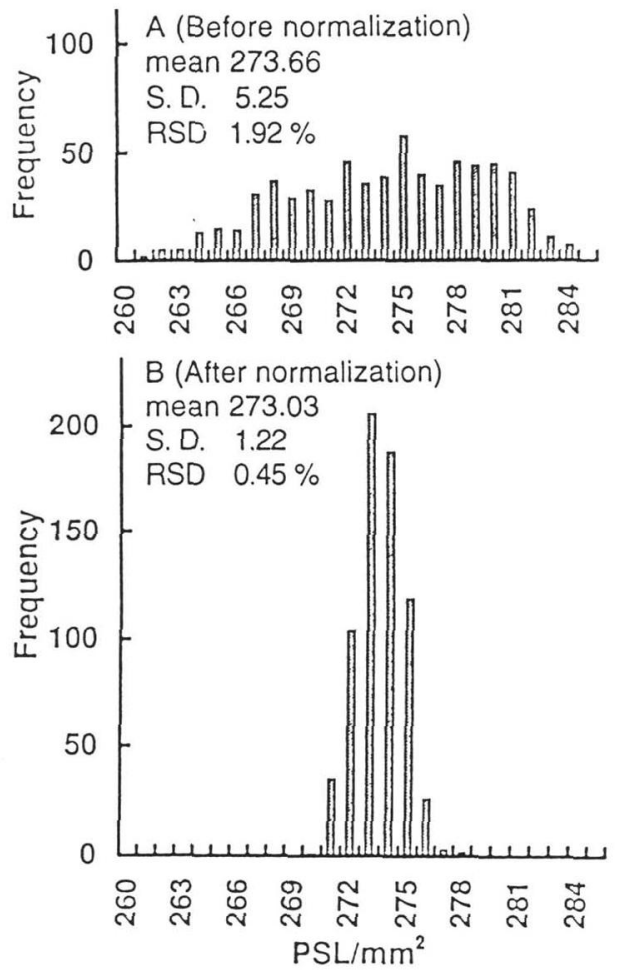

Fig. 1 Variances of PSL in the IP exposed to a ${ }_{147} \mathrm{Pm}$ planar radiation source for $10 \mathrm{~min}$

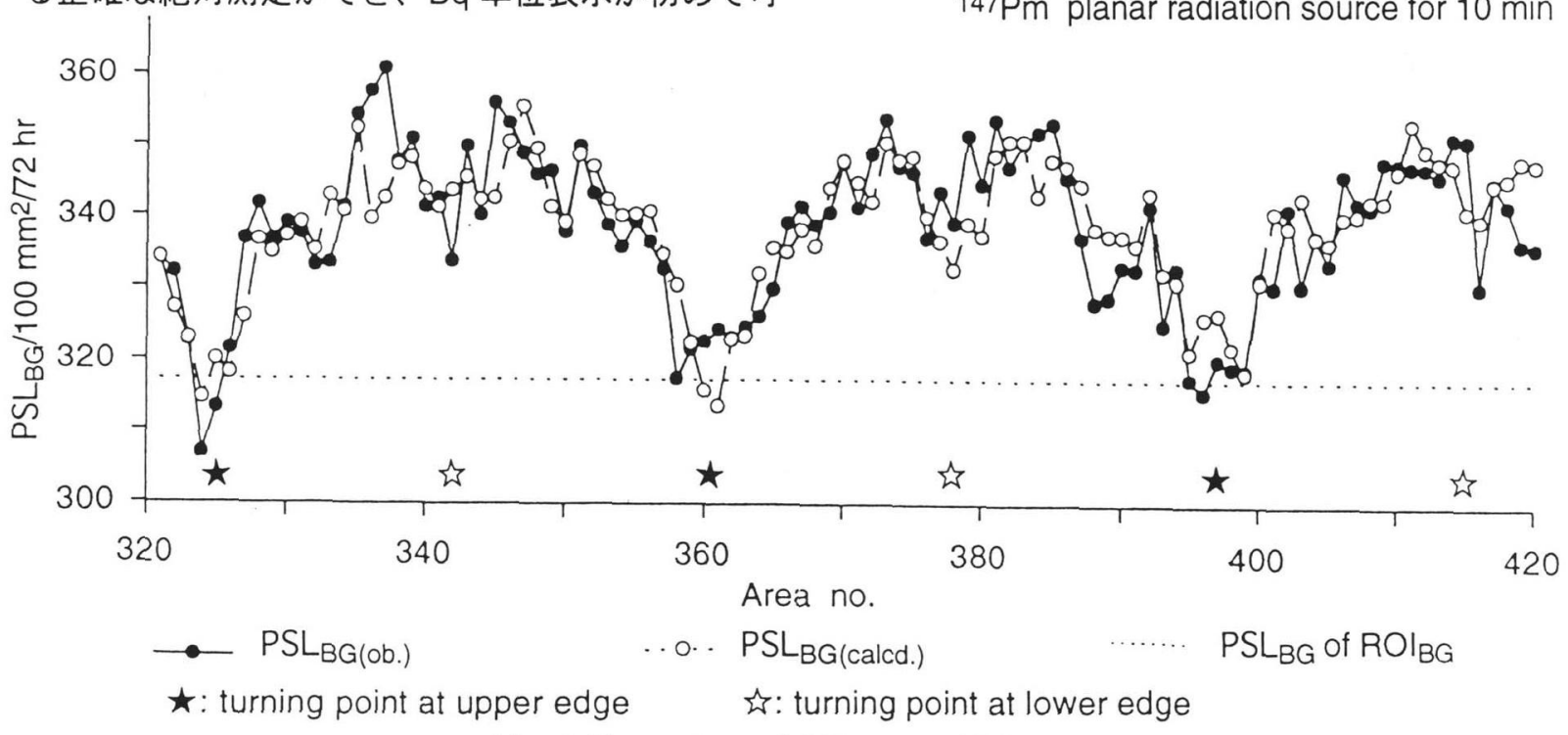

Fig. 2 Fluctuation of $P S L_{B G}$ and $P S L_{B G}$ (calcd.)

[ABSTRACT] The uniformity in $B$-ray sensitivity was examined by exposing IP to a $147 \mathrm{Pm}$ planar radiation source followed by analyzing with BAS. An area dependency of appreciable extent in B-ray sensitivity was observed, which could be mainly attributed to the mechanics in BAS. A correction method for this area dependency was presented. A method for measuring directly the PSL $B G$ of each area and examining radioactive contamination of IP was developed, which involved exposing IPs simultaneously and assessing $P S L_{B G}$ of the IP in contact with a sample from the PSL $L_{B G}$ of the corresponding area in the other IPS.

[REFERENCES] 1) RLG 研究会; バリデーション検討分科会最終報告(1998). 2) S. Baba et al. ; Appl. Rad. Isot. 48, 953 (1997). 3) S. Baba et al. ; Proceedings of Synthesis and Applications of Isopically Labelled Compounds, Strasburg, France, 20 - 24 June 1994, pp $843-847$ edited by J. Allen, John Wiley Sons. 